ISSN 0258-7122

Bangladesh J. Agril. Res. 37(2): 301-306, June 2012

\title{
EVALUATION OF SOME SELECTED AGRONOMIC CHARACTERS ON YIELD OF CHILLI CULTIVARS/LINES USING ANALYSIS OF COVARIANCE
}

\author{
M. ASIF MASOOD ${ }^{1}$, KHALID MAHMOOD KHOKHAR ${ }^{2}$ AND IRUM RAZA $^{1}$
}

\begin{abstract}
The study was carried out to see the effect of some agronomic variables on yield of chilli cultivars/lines using covariance analysis technique. Data were recorded for yield and other six agronomic variables, namely time to flowering (days), time to maturity (days), fruit weight per plant in grams, average fruit weight in grams, fruit width in centimeters, and fruit length in centimeters. Among six agronomic variables, fruit weight per plant (grams) is highly significant and linearly related to the plant yield having value of correlation coefficient (r) 0.99 whereas average fruit weight (grams) was significant at 5 percent and linearly related to the yield having correlation coefficient value 0.55 . Analysis of variance (ANOVA) and analysis of covariance (ANCOVA) were run by taking fruit weight per plant (grams) as covariate. The error mean square (EMS) without covariate was 1.344 under ANOVA, while error mean square was 0.007 under ANCOVA with covariate. The results depicted that use of covariate reduced error mean square in ANCOVA. It indicated that ANCOVA is more efficient than ANOVA for improving the results of the experiment.
\end{abstract}

Keywords: ANOVA, ANCOVA, error mean square, chilli cultivars/lihes, agronomic variables and correlation analysis.

\section{Introduction}

The covariance analysis minimizes the variability among experimental units by adjusting their values to a common value of the covariate. Mahmood Zafar et al., 2007 reported that the error sum of square for panicle number per hill $(\mathrm{Y})$ is 321.20 with 40 degrees of freedom giving MSE $=8.03$, and the value of effective mean square error is equal to 3.588 when covariance is used. This indicates that ANCOVA is more efficient.

Kuehi, 2000 reported that in covariance analysis, values for treatment means in the research study depend on covariates that vary among the experimental units and have significant relationship with the primary response variable. It is believed that concomitant variables or covariates can be measured at any time in an experiment and their influence on the response variable can be assessed by analyzing the data using combined covariance regression methodology with analysis of variance. Some important uses of covariance analysis in agricultural

${ }^{1}$ Biometrics Programme, ${ }^{2}$ Vegetable Progamme, National Agricultural Research Centre, Islamabad, Pakistan. 
research are to control experimental error and to adjust treatment means to reduce mean square error by this means improvement in the precision of the experiment; and to estimate missing values. In this context, an experiment was conducted to find out the possible correlation between yield and some selected agronomic characters; compare Mean Square Error under analysis of variance (ANOVA) and analysis of covariance (ANCOVA)

\section{Materials and Method}

The experiment was conducted by Vegetable Program, NARC during 2007- 08 at National Agricultural Research Centre (NARC). The experiment was laid out in Alpha Lattice Design with two replications, 25 cultivars/lines of chilli, 5 lines per block and 5 blocks in each replication. The data were recorded on flowering (days), maturity (days), fruit weight $(\mathrm{g})$, width $(\mathrm{cm})$, and fruit length $(\mathrm{cm})$. Correlation matrix, analysis of variance (ANOVA), analysis of covariance (ANCOVA) and least significant difference (LSD) techniques were used for the analysis. RCBD was used without and with covariates to estimate effect of covariate on yield and to compare ANOVA and ANCOVA error mean square under both models. All the statistical analyses were done by using MINITAB software version 15 . Analysis of variance and covariance analysis were done to examine the effect of agronomic variables on yield variable. Gomez and Gomez, 1984 highled the use of covariance for reducing the experimental error as swell as standard error of means.

\section{Results and Discussion}

Analysis of variance (ANOVA) was used to observe the statistical difference among chilli lines/cultivars in relation to yield and yield attributes. Concise mean table, corrletaion analysis, ANOVA and analysis of covariance (ANCOVA) are summarized in (Table 1-4), respectively. Means were separated using least significant difference (LSD) test (Table 1). Chilli lines $(5,11)$ and "Lounghi cultivar 23" indicated highest days to flowering followed by the lines $8,18,20,1,4,6,7,21,22,17$, and cultivar 24 . However, the mean yield difference among these lines/cultivars were statistically non-significant. "line 11" was yielding significantly greater than "Line 5" and "cultivar 23" whereas "Line 15" showed lowest days to flowering. Cultivar 23 gave heightest mean days to maturity (87.5) as compared to other lines/cultivars. When line 16 revealed lowest mean for days to maturity. Culitvar 23 revealed highest fruit width than other cultivars/lines. Line 20 gave lowest mean fruit width among all the cultivars/lines in the study. Line 3 showed largest mean fruit length $(12.9 \mathrm{~cm})$ and cultivar 23 lowest $(3.7 \mathrm{~cm})$, respectively. Line 4 indicated higest mean for weight of fruit (451g), while line 20 lowest mean (142 g). Line 4 ICPN 1544 gave highest fruit yield (12.04 t/ha) all the cultivars and linnes followed by 
lines/cultivars 4,25,18,5,17, 15, and 7. However, statistically, the mean yield differences were non-significant. The lowest yield (3.80 t/ha) was given by line "PBC 462" whereas ICPN line provided the lowest yield (Table 1).

Table 1. Plant characters and yield attributes of chilli lines/ cultivars.

\begin{tabular}{|c|c|c|c|c|c|c|}
\hline Lines/ cultivars & $\begin{array}{l}\text { Days to } \\
\text { flowering }\end{array}$ & $\begin{array}{l}\text { Days to } \\
\text { maturity }\end{array}$ & $\begin{array}{l}\text { Fruit } \\
\text { width } \\
(\mathrm{cm})\end{array}$ & $\begin{array}{c}\text { Fruit } \\
\text { length } \\
(\mathrm{cm})\end{array}$ & $\begin{array}{c}\text { Wt of } \\
\text { fruit } \\
\text { (g) }\end{array}$ & $\begin{array}{l}\text { Fruit yield } \\
\qquad(\mathrm{t} / \mathrm{ha})\end{array}$ \\
\hline 1 ICPN 15\#1 & $54.50 a-b$ & 73.00 c-e & $1.36 f-h$ & 8.05 g-h & $257 e-j$ & $6.86 \mathrm{e}-\mathrm{i}$ \\
\hline 2 ICPN 15\#2 & $46.00 \mathrm{e}-\mathrm{g}$ & 71.50 de & $1.02 \mathrm{j}-\mathrm{m}$ & $9.88 \mathrm{~d}-\mathrm{f}$ & $240 \mathrm{f}-\mathrm{k}$ & $6.42 \mathrm{f}-\mathrm{j}$ \\
\hline 3 ICPN 15\#3 & 48.00 e-f & $76.00 \mathrm{~b}-\mathrm{c}$ & $1.71 \mathrm{~b}-\mathrm{c}$ & $12.9 \mathrm{a}$ & 289d-h & 7.73 c-g \\
\hline 4 ICPN 15\#4 & 53.50 a-c & $76.00 \mathrm{~b}-\mathrm{c}$ & 1.14 i-k & $8.56 \mathrm{~g}$ & $451 \mathrm{a}$ & $12.04 \mathrm{a}$ \\
\hline 5 ICPN 15\#5 & $56.50 \mathrm{a}$ & $78.50 \mathrm{~b}$ & $1.63 \mathrm{c}-\mathrm{d}$ & $9.28 \mathrm{f}$ & 399a-c & $10.65 \mathrm{ab}$ \\
\hline 6 ICPN $15 \# 6$ & $53.00 \mathrm{a}-\mathrm{c}$ & 73.00 c-e & $1.04 \mathrm{j}-1$ & 9.8 e-f & 212g-I & $5.67 \mathrm{~g}-\mathrm{j}$ \\
\hline 7 ICPN 15\#7 & 53.50 a-c & $76.00 \mathrm{~b}-\mathrm{c}$ & $1.400 \mathrm{e}-\mathrm{g}$ & $1.38 \mathrm{c}$ & 363a-d & 9.69 a-d \\
\hline 8 ICPN 15\#8 & $55.00 \mathrm{ab}$ & $75.00 \mathrm{~b}-\mathrm{d}$ & $0.891-n$ & $8.25 \mathrm{~g}$ & 282d-i & $7.41 \mathrm{~d}-\mathrm{h}$ \\
\hline 9 ICPN 15\#9 & $49.00 \mathrm{c}-\mathrm{f}$ & 74.00 c-e & $1.19 \mathrm{~g}-\mathrm{j}$ & $10.51 d-f$ & 337b-e & $9.01 \mathrm{~b}-\mathrm{f}$ \\
\hline 10 ICPN 15\#10 & $46.00 \mathrm{e}-\mathrm{g}$ & 71.50d-e & $1.15 \mathrm{~h}-\mathrm{k}$ & $12.01 \mathrm{~b}-\mathrm{c}$ & 235g-k & $6.29 \mathrm{f}-\mathrm{j}$ \\
\hline 11 ICPN 16\#1 & $57.00 \mathrm{a}$ & 78.50 b & $0.851-n$ & $5.86 \mathrm{i}$ & $164 \mathrm{j}-1$ & $4.38 \mathrm{i}-\mathrm{j}$ \\
\hline 12 ICPN $16 \# 2$ & $45.50 \mathrm{f}-\mathrm{g}$ & 71.50 d-e & $0.84 \mathrm{I}-\mathrm{n}$ & $10.52 \mathrm{~d}$ & 233g-k & $6.23 \mathrm{f}-\mathrm{j}$ \\
\hline 13 ICPN $16 \# 3$ & 50.50 b-e & $71.50 \mathrm{~d}-\mathrm{e}$ & 1.58 c-e & $10.26 \mathrm{~d}-\mathrm{f}$ & $324 c-f$ & 8.66 b-f \\
\hline 14 ICPN $16 \# 4$ & $48.50 \mathrm{~d}-\mathrm{f}$ & 71.50 d-e & $1.27 \mathrm{f}-\mathrm{i}$ & $9.50 \mathrm{f}$ & 355b-d & 9.48 a-e \\
\hline 15 ICPN $16 \# 5$ & $43.00 \mathrm{~g}$ & 71.50 d-e & $1.45 \mathrm{~d}-\mathrm{f}$ & $12.16 \mathrm{~b}$ & 387a-c & 10.33 a-c \\
\hline 16 ICPN $16 \# 6$ & $48.50 \mathrm{~d}-\mathrm{f}$ & $71.00 \mathrm{e}$ & 0.96 k-n & $9.41 \mathrm{f}$ & 284d-i & 7.59 c-g \\
\hline 17 ICPN $16 \# 7$ & $53.00 \mathrm{a}-\mathrm{d}$ & $78.50 \mathrm{~b}$ & $1.62 \mathrm{c}-\mathrm{d}$ & $11.51 \mathrm{~b}-\mathrm{c}$ & 395a-c & 10.55 a-b \\
\hline 18 ICPN $16 \# 8$ & $55.00 \mathrm{ab}$ & 71.50 d-e & $1.00 \mathrm{j}-\mathrm{n}$ & 10.27d-e & $404 a-c$ & $10.79 a-b$ \\
\hline 19 ICPN 16\#9 & $45.00 \mathrm{fg}$ & $76.00 \mathrm{~b}-\mathrm{c}$ & $0.99 \mathrm{j}-\mathrm{n}$ & $7.37 \mathrm{~h}$ & 222g-I & $5.67 \mathrm{~g}-\mathrm{j}$ \\
\hline 20 PBC 462 & $55.00 \mathrm{ab}$ & 74.00 c-e & $0.80 \mathrm{n}$ & $7.49 \mathrm{~h}$ & 1421 & $3.80 \quad \mathrm{j}$ \\
\hline 21 CCA 7244 & $53.50 \mathrm{a}-\mathrm{c}$ & 74.50 c-e & 0.86 I-n & $9.35 \mathrm{f}$ & $179 \mathrm{j}-1$ & $4.79 \mathrm{~h} \mathrm{-j}$ \\
\hline 22 9907-9611 & $53.50 \mathrm{a}-\mathrm{c}$ & $76.00 \mathrm{~b}-\mathrm{c}$ & $0.881-n$ & $9.81 \mathrm{~d}-\mathrm{f}$ & 200i-I & $5.35 \mathrm{~g}-\mathrm{j}$ \\
\hline 23 Lounghi & $56.00 \mathrm{a}$ & $87.50 \mathrm{a}$ & $2.03 \mathrm{a}$ & $3.71 \mathrm{k}$ & 203h-I & $5.42 \mathrm{~g}-\mathrm{j}$ \\
\hline 24 NARC-4 & $53.00 \mathrm{a}-\mathrm{d}$ & $76.00 \mathrm{~b}-\mathrm{c}$ & 0.81 m-n & $5.35 \mathrm{i}-\mathrm{j}$ & 292d-g & 7.80 c-g \\
\hline 25 Nepali & $47.00 \mathrm{e}-\mathrm{g}$ & $76.00 \mathrm{~b}-\mathrm{c}$ & 1.89 a-b & $4.78 \mathrm{j}$ & 413a-b & $11.04 \mathrm{a}-\mathrm{b}$ \\
\hline LSD (0.05) & 4.723 & 1.826 & 0.219 & 0.719 & 88.641 & 2.393 \\
\hline
\end{tabular}

Variable means followed by the same letter donot differ significanlly at 5 percent level 
Prior to analysis of covariance of experimental data, the correlation analysis was carried out between yield and rest of the agronomic characters (Table 2). Among all these agronomic characters, only the agronomic characters, such as fruit weight per plant (g) and average fruit weight (g) were significantly related with yield. Their correlation coefficients were 0.999 and 0.546 , respectively, and they were significant at $(\mathrm{P}<.0 \mathrm{l}$ and $\mathrm{P}<0.05)$, respectively.

Table 2. Correlation analysis of yield against the agronomic characters.

\begin{tabular}{ll}
\hline Agronomic Characters & Simple correlation coefficients (r) \\
\hline Time to flowering (Days) & $-0.115^{\mathrm{NS}}$ \\
Time to maturity (Days) & $-0.067^{\mathrm{NS}}$ \\
No. of fruits per plant & $0.115^{\mathrm{NS}}$ \\
Fruit wt per plant (g) & $0.999^{* *}$ \\
Average fruit wt (g) & $0.546^{*}$ \\
Average width (cm) & $0.418^{\mathrm{NS}}$ \\
Average fruit length (g) & $0.235^{\mathrm{NS}}$ \\
\hline
\end{tabular}

$* *=$ Significant at $1 \%$ probability level, $*=$ Significant at $5 \%$ probability level and ${ }^{\mathrm{NS}}=\mathrm{Not}$ Significantly different at $5 \%$ probability level

F-values for chilli lines/cultivars on yield and yield attributes are summarized in Table 3. The results indicate statistical significant difference among twenty five (25) cultivars/lines of chilli from days to flowering, days to maturity, fruit width $(\mathrm{cm})$, fruit length $(\mathrm{cm})$, weight of fruit $(\mathrm{g})$, and fruit yield (t/ha), respectively (table 3).

Table 3. Analysis of variance (F-vlaues) for chilli lines/ cultivars on yield and yield attributes.

\begin{tabular}{l|l|l|l|l|l|c|c|c}
\hline \multicolumn{1}{c|}{ S.O.V. } & DF & MSE & $\begin{array}{c}\text { Days to } \\
\text { flowering }\end{array}$ & $\begin{array}{c}\text { Days to } \\
\text { maturity }\end{array}$ & $\begin{array}{c}\text { Fruit } \\
\text { width } \\
\text { (cm) }\end{array}$ & $\begin{array}{c}\text { Fruit } \\
\text { length } \\
\text { (cm) }\end{array}$ & $\begin{array}{c}\text { Wt } \\
\text { of fruit } \\
\text { (g) }\end{array}$ & $\begin{array}{c}\text { Frui } \\
\text { yield } \\
\text { (t/ha }\end{array}$ \\
\hline Replications & 1 & 1.348 & $1.10 \mathrm{~ns}$ & $1.17 \mathrm{~ns}$ & $0.10 \mathrm{~ns}$ & $1.12 \mathrm{~ns}$ & $1.23 \mathrm{~ns}$ & $1.00 \mathrm{r}$ \\
Cultivars/lines & 24 & 11.101 & $6.55^{* *}$ & $7.77^{* *}$ & $23.11^{* *}$ & $90.44^{* *}$ & $8.37^{* *}$ & $8.261^{*}$ \\
Error & 24 & 1.344 & & & & & \\
\hline
\end{tabular}

Analysis of covariance was also used on the same yield along with covariates that were not significantly related with the fruit yield (Table 4). This indicates that the cultivars/lines effect was also significantly different on fruit yield at 0.01 percent level of significance, as was found with the analysis of variance. Also the 
mean square value in case of analysis of variance was 1.344 and it was 0.007 after using analysis of covariance. This implies that analysis of covariance is a powerful technique in reducing mean square error.

Table 4. Analysis of covariance (F-values) for chilli cultivars/lines on yield and yield attributes.

\begin{tabular}{|c|c|c|c|c|c|c|c|c|}
\hline $\begin{array}{l}\text { Source of } \\
\text { variation }\end{array}$ & DF & MSE & $\begin{array}{c}\text { Time to } \\
\text { flowering } \\
\text { (days) }\end{array}$ & $\begin{array}{l}\text { Fruit } \\
\text { width } \\
(\mathrm{cm})\end{array}$ & $\begin{array}{c}\text { Time to } \\
\text { maturity } \\
\text { (days) }\end{array}$ & $\begin{array}{c}\text { Fruit } \\
\text { length } \\
(\mathrm{cm})\end{array}$ & $\begin{array}{c}\text { Average } \\
\text { fruit } \\
\text { wt } \\
(\mathrm{g})\end{array}$ & $\begin{array}{c}\text { Fruit } \\
\text { wt/ } \\
\text { plant } \\
\text { (g) }\end{array}$ \\
\hline Replication & 1 & 0.014 & $1.28^{\mathrm{NS}}$ & $0.73^{\mathrm{NS}}$ & 0.75 & $1.02^{\mathrm{NS}}$ & $0.85^{\mathrm{NS}}$ & 2.05 \\
\hline cultivars/lines & 24 & 0.0066 & $8.00 * *$ & $6.41^{* *}$ & $7.94 * *$ & $7.44 * *$ & $5.80 * *$ & $0.96^{\mathrm{NS}}$ \\
\hline Covariate & 1 & 32.107 & 0.58 & 0.27 & 0.21 & 0.06 & 2.05 & $4620.43^{*}$ \\
\hline Error & 23 & 0.0069 & & & & & & \\
\hline Total & 49 & & & & & & & \\
\hline
\end{tabular}

Follow up of the results obtained from the correlation analysis, covariance analysis was further carried out and the result of this analysis obtained from the experimental data are given in (Table 4). Analysis of covariance revealed that fruit weight per plant (g) was the only covariate, which was significantly related with the chilli cultivars/lines, which is not significantly affecting the yield after adjusting the yield variable by the effect of this covariate.

The covariance analysis is very useful for improving the precision of an experiment (Montgomery, D.C. 2005). The treatment mean is adjusted to the value like if there have been no differences in the values of the covariate (Steel and Torrie, 1980).

\section{Conclusion}

In this study, plant characters of chilli were evaluated to find out the effect of chilli cultivars/lines. The only covariate fruit weight per plant highly influenced the yield of chilli cultivars/ lines. Use of covariate reduced the error mean square in the analysis of covariance as compared to standard analysis of variance by eliminating the effect of variations caused by covariates. Additional measurement as a covariate improved the precision of experimet by adjusting treatment effect. Covariance analysis should be applied to such data where the covariates are present to improve the quality of analysis. 


\section{References}

Gomez, A.K. and A. A. Gomez. 1984. Statistical Procedures for Agricultural Research $2^{\text {nd }}$ Edn., John Wiley and Sons Inc.

Kuehl, R. O. 2000. Design of Experiments: Statistical Principles of Research Design and Analysis. $2^{\text {nd }}$ Edition Duxbury Press at Brooks/Cole Publishing Company, Pacific Grove, CA 93950 USA www.brooksscile.com666pp.

Montgomery, D.C. 2005. "Design and Analysis of Experiments", 7th edition.

Steel and Torrie. 1980. "Principle and Procedures of Statistics", $2^{\text {nd }}$ ed. USA Mc Hill, 428-434.

Zafer M., Salahuddin., Jan Bahrawar, Zahid., and Idress Muhammad. 2007. “Adjustment of the treatment effects by controlling covariates in agricultural research". Sarhad J. Agric. 23(2). 509-513 